\title{
The Right of Property and its Juridical Protection - Albania Case
}

\author{
Sofiana VELIU \\ sofjana.veliu@uet.edu.al
}

Koordinatore, Departamenti i edukimit,komunikimit, dhe maredhenieve me publikun

\begin{abstract}
Selected theme, aims to highlight some of the current issues concerning the right of property as one of the fundamental human rights. Although the Albanian Constitution provides and guarantees the right of ownership, there are a lot of problems regarding the practical effectiveness of these arrangements, the executive titles of ownership and prior compensation in the case of the removal of this right Consequently, the current situation clearly shows that, there is still superposition of these ownership titles and very little legal protection, because the transactions remain informal action apparently by law.According to the analysis of ECHR decisions and EC's recommendations, in some cases, there is a "gap" between law and practice of the Albanian courts and international directions, causing crash between European standards and Albanian legal culture. In the context of respect and guarantee of the fundamental human rights, it's necessary a great commitment to complete and consolidate the system of property in general and essentially not violated these rights. The consolidation and guarantee of ownership it's closely related to the consolidation of the democratic state .
\end{abstract}

Keywords: private property rights, European integration, expropriation and restrictions of private property rights, the decisions of the Strasbourg court, liberal democracy

\section{Introduction}

Today, property rights issues are still a major concern in Albania... Property rights issues are still considered today a major concern regarding the general development of the Albanian economy. Real estate market is constantly facing various challenges that in a considerable number originate from the lack of a clear functioning administration system of immovable property rights. On the other side, many unresolved cases of land property ownership are waiting to be processed from the Albanian judicial authorities, while the number of cases addressed to the European Court of Human Rights is increasing. Turning back to 1990-s, the change of political system that country experienced in the early 1991 paved the way to a wide national range of privatization process of the state owned and common properties, as those were considered before ' 90 . The new transformation process required the creation of private ownership and subordinate rights on its initial phase, taking as a basic reference the four main categories of land and property use, such as housing properties, agricultural fields, industrial or service buildings and lands, as well as properties being claimed for restitution by their legally documented owners before 1945. In addition to these categories, properties under state and municipal ownership were also at issue of newly amended laws on privatization and land property rights. However, despite the institutional and legal action taken by the authorities to implement land and property rights reform during' 90 -s, political, economic and demographic changes that took place vitally in these years, created confusion and difficulties in implementing laws and controlling the land. Property rights issues in Albania: Challenges and perspective 9 Internal migration resulting in unauthorized and unregistered properties...

\section{Internal migration resulting in unauthorized and unregistered properties...}

Along the first years of transition, Albania witnessed a fast internal migration, from mountainous and rural areas towards urban and peri-urban ones, a demographic shift in search of better living conditions and economic opportunities; phenomenon which resulted in numerous buildings without permit and land occupation without legal authorization, mainly situated in periphery of capital or other cities located in western country's' lowland. Consequences of these continuous demographic movements are now the peripheral "informal" urban areas of large cities or occupied seaside territories. A considerable share of today's total of Albanian immovable properties consists in such unauthorized and unregistered land plots and illegal buildings. 
In 1994, was adapted the Law on the Registration of Immovable Property where a new property registration system based on land parcels was introduced. In this light, was established also the Immovable Property Registration Office (IPRO), as the managing authority in charge to administer the process. Facing numerous challenges because of a missing nationwide commitment towards systemic initial registration, until 2010 IPRO estimated that it has records for some 60-70 percent of all properties 1 , having completed initial registration for 83 percent of rural cadastral zones, but only 25 percent of urban cadastral zones.

\section{The three main factors of system's weaknesses...}

In the World Bank Report of 2006, "Status of land reform and property rights in Albania", it is concluded that the system's weaknesses appear to be result of three main factors.

The first of these factors is considered absence of the agreement on what would be the best method to achieve the reform's aims despite the wide accepted goals that land and property reform should have, and because of this several fundamental policy decisions remain unimplemented.

Second, the reforms have been applied in a categorical manner-that is, with different legal definitions for agricultural, forest, pasture, urban housing, commercial, industrial and other lands or properties, creating so a highly complex system with many gaps and overlaps.

And the third factor is evaluated to be the fragmentation of property units and land parcels requiring in this way the engagement of each owner in multiple subsidiary arrangements to accomplish routine property use. Taken together, these factors have made it difficult to adapt the models of European civil law and market relations within Albanian environment, slowing the progress of reform and letting the system vulnerable to the growth of informal and corrupt practices.

\section{Developments in immovable property rights reforms}

\section{Constructions classified as illegal nationwide are more than 350,000 buildings...}

As a result of rapid internal migration in years and absence of an official mechanism to allocate land for a large number of newcomers, a considerable number of individuals simply occupied the land and built without permits. But, in addition also lack of effective urban planning and construction controls, eased additions and expansions of existing constructions that are now also considered illegal. Thus, today, constructions classified as illegal nationwide reach an estimated number of more than 350,000 buildings which over the years have been subject to numerous informal transactions on selling and acquiring them. These transactions occurred without the proper documentation of property ownership and because of this, the ownership rights are not legally known to the new owner; so, no legal protection adheres fully owners whose properties are informal, from the legal point of view.

\section{A national centralized professional agency to manage the legalization process...}

Aiming to solve this major issue of the real estate sector, legalization process was treated by the authorities as an effective response to the increasing number of urban and economic problematic rising from mass illegal land occupation and settlements. Through this process, Albania's legalization policy tends to formalize illegal constructions, legally transfer ownership of the land on which they were built, and expand urban planning towards informal settlements. For this purpose, a national centralized professional agency was created to manage the legalization process. The Agency for the Legalization, Urban Planning, and Integration of Informal Areas/Constructions (ALUIZNI) was established by the amended Law on Legalization. As a large organization with operating costs covered by the state budget, ALUIZNI is mandated to process legalization applications and coordinate the legalization process in a nationwide level. Basing on aerial photographs taken in 2006, the agency has completed administrative procedures for almost $80 \%$ of these buildings which were erected prior to 2006. Legalization permits have been granted for 52000 properties, Property rights issues in Albania: Challenges and perspective 13 which have also been included into the system of immovable properties registration. Around 100000 informal properties are in the process of preparing the legal-technical documentation. 127 informal zones and dwellings 
have been approved by the National Territory Regulation Council, including 120000 properties ${ }^{1}$. Around 80000 informal buildings have been approved by the local council of territorial regulation, included as blocks of informal residences or treated as separate buildings and extensions to the legally constructed buildings. The Law on Legalization applies only to buildings constructed before May 2006 and for which legalization applications were submitted by November 15, 2006. The ongoing legalization process leaves out a large number of informally constructed buildings, therefore, in order to prevent construction of other illegal buildings at the present situation, a new legalization campaign focused on illegal buildings after 2006 will need to take place.

\section{On Restitution and Compensation of properties to former owners...}

Another related issue which cannot be viewed isolated from legalization and privatization process is the restitution and compensation of land to former owners. Law number 7698 of April 15, 1993, On Restitution and Compensation to Former Property Owners was the first law to be adapted focusing on restitution and compensation of land. After its adoption, identified as the first phase, many properties were restituted to former owners or their descendants basing on legal documents proving ownership while in the case of agricultural land, the ownership was known to those who worked it. In the second phase of the process, the main issue was compensation of properties, for which the restitution was not possible. In the policy content angle of view, the Law On Restitution and Compensation of Property adopted in 2004 takes a similar approach to that adopted by other countries in Central and Southeastern Europe. However, the requirement to compensate expropriated owners at current market value is difficult to implement due to high fiscal costs.

\section{Property Restitution and Compensation Agency...}

From 2006, Property Restitution and Compensation Agency (AKKP) is the responsible authority for managing the restitution and compensation process in Albania. The restitution and compensation process was delayed initially, as the legal framework contained uncertainties, including on the valuation methodology and role of various government bodies. In 2006, amendments to the Law on Restitution and Compensation of Properties established the AKKP and transferred to it the functions of restitution and compensation previously held by the central government and local committees. These amendments aimed to increase the effectiveness and pace of the process, but these expectations have not been met3 . AKKP manages also the Physical Compensation Fund and verifies regularly its juridical situation. Until today, are taken more than 25200 compensation decisions, from which 16000 giving only the right of compensation for the land known. In total, are known around 55283 hectares of land, from which 7333 hectares construction land, 43100 hectares of agricultural land, 4000 hectares of forest land, and 850 hectares of combined cases for compensation ${ }^{2}$.

\section{Difficulties in the precise identification of immovable properties...}

Authorities often face difficulties in the precise identification of immovable properties depending on some further processes, such as the process of initial registration, legalization, transfer of state owned property to local government units, completion of the territorial plans, including regulatory plans in coastal zones, as well as digitalization. Consequently, the compensation in kind of expropriated persons has not started yet massively and this is due to the absence of a solid compensation scheme. One of the main challenges the authorities are facing is the poor data quality that depends mainly on the results of the ongoing digitalization process. Improving data quality will significantly facilitate the precise identification of properties and establish the credibility on land registries. Amendments made to the Law on Restitution and Compensation of Property, set new criteria for land evaluation and extend the deadline for property restitution and compensation to 2014 .

\section{Judgment statistics of Strasbourg Court on Albanian cases...}

\footnotetext{
1 "Crosscutting Strategy Reform in the Field of Property Rights 2012 - 2020", Ministry of Justice, Republic of Albania, June 2012

2 Governance in the Protection of Immovable Property Rights in Albania: A Continuing Challenge", World Bank Report No:62519-AL , June 2011 
Referring to the judgment statistics of ECtHR until $2010^{1}$, the Albanian cases judged by the Court that have as a judgment matter the "Protection of property", constitute $22 \%$ of the total while "Right to a fair trial" reach the level of $44 \%$ of the total number of judged cases. The Court found violations in $85 \%$ of the decisions given, and only $4 \%$ of them with no violation.

\section{Some progress was achieved in the area of property rights...}

According to the same EC Report some progress was achieved in the area of property rights, notably through the adaption of a new law on registration of immovable property and through the adaption of a cross-cutting strategy and action plan, but still it is considered that a lot remains to be done in the fields of land registration and of restitution of property to former owners. The process of initial registration of immovable property has not yet been completed. Lack of secure property rights and the weak institutions remain causes for concern and further efforts are required to address these issues. Weaknesses remain in the rule of law, particularly in contract enforcement and property rights, while the executive has yet to communicate a clear timetable for enforcement of ECtHR judgments regarding property rights.

\section{Scenarios on improving property rights administration system}

Property administration is a crucial issue for the general development of a country. This process, based on the fundamental human right of ownership, is tightly related with the economic welfare, market well-functioning, employment and investment potential that a country represents. Titled properties and specified property rights help to project and improve urban planning as well as to develop infrastructure, providing ground to implement state reforms. In order to be efficient, the system of property administration should guarantee property ownership and tenure security, serving to the enhancement of a stable real estate sector, reducing land disputes, facilitating immovable property transactions and supporting good governance.

Aiming to increase efficiency of state authorities dealing with immovable property rights issues, Albanian government has gone through many reforms. A lot of progress is achieved but what is concluded in different country reports on property rights issues is that there are still many challenges ahead and room for faster progress in solving property rights issues. Related studies and success stories from economies with similar concerns, evidence that effective implementation of reforms is possible, relying on the continuity of a transformation process oriented by the efficiency of state agencies serving to build and consolidate the property administration system ${ }^{2}$.Some potential scenarios on improving the performance of property rights administration system could be as following:

First view: More effective and efficient property rights institutions. Single Agency Model The country's chaotic immovable property market and the stakeholder's concerns about property rights have raised the attention on the importance of effectiveness of state agencies responsible on these issues. Regardless an adopted and improved legal framework for private ownership during the years, a responsive and accountable system of land administration is needed to support property market developments. In Albania as in other countries of the region, insecure and uncertain property rights continue to be a barrier to a long-term solution of the property issues and as a result, a barrier to investment and a constraint on economic development. State agencies such as IPRO, AKKP and ALUIZNI should enhance their coordination to ensure a fast, well-operating and incontestable property rights administration system. In the same length of wave should be the cooperation between central and local government. Unification of immovable properties database applying the same technical standards and requirements, basing on commonly accepted ownership documents compatible to cartographic data is an important process conditioning further developments on property market. More effective land administration system means primarily customer service oriented agencies with the objective of supporting land and property market development. More efficient property registration procedures would reduce transaction costs and enhance the security of property rights. These improvements on the system would benefit to all stakeholders related to property rights issues, building and consolidating trust in authorities.

\footnotetext{
1 http://www.echr.coe.int/NR/rdonlyres/E6B7605E-6D3C-4E85-A84D-6DD59C69F212/0/Graphique_violation_en.pdf

2 Stanley and Adlington (2007)"World Bank Experience in Land Administration in the Transition Economies of Eastern Europe and Central Asia" 


\section{The alternative of a single agency...}

An alternative solution on achieving an efficient and effective property rights administration system is the creation of a single agency dealing with all kinds of property issues. The UNECE guidelines for land administration9 recommend that a single agency to be responsible for land administration. Single agency models have certain advantages: they can operate more efficiently and cheaply than multiple agency models; the cadaster and legal data are naturally linked and harmonized; automation is simpler and less costly; and it is easier to be financially self-sustainable. Success stories on solving property rights issues through reforming the system and building a single efficient as well as effective agency dealing with property issues could be found in countries with similar specifics. ${ }^{1}$

In case of Albania, depending on successful finalization of the digitalization process of all cadastral registrars, potential steps towards the creation of a single agency could begin with simplification and combination of procedures basing on same standards, easing the access to land registrars and to conclude in restructuring, linking as unifying different agencies involved in immovable property issues into a single one, A merger of key agencies involved in the regulation of immovable property rights under a combined mandate would improve coordination of procedures, service quality and reduce operating costs relying on a smaller but more professional and better qualified personnel organic. The aim that citizen is central to the work of land administration agencies requires a change in orientation and service organization. In this light, dedicated service sections could be attributed to citizens, organizations and investors, responding requests linked to immovable property issues in order to facilitate procedures.

Second view: A different approach on monitoring reforms implementation...

The right pace of reforms implementation determines the level of impact on improving property rights administration system. Many projects funded by government and donor institutions aiming to improve the property rights reality still didn't solve the major concerns on these issues. Progress is slow and the outcome of reforms not as expected. A wider inclusion of stakeholders and civil groups in reforms implementation would raise effectiveness of the initiatives taken. Important part of this process could be joint committees of government officials, international experts on immovable property reforms and civil society professionals that will monitor in continuous basis the implementation of reforms and evaluate step by step the contribution of reforming process in the sustainable development of this sector.

Third view: Building confidence through transparency and easy access to data

In order to accomplish agencies mission on property rights and develop a sustainable functioning system, along with the harmonization of property rights legislation and consolidation of institutions, a special attention from the authorities should be dedicated to building public confidence in property administration system.

Public debate fostering institutional consolidation... Creating a public discussion platform on property rights issues to exchange information, share experience and co-ordinate among institutional actors, public, academics and civil society will be important to include all stakeholders in the process of reforming property rights system. This platform would serve as a unified source of all agencies to inform and discuss with citizens on the latest decisions, and in the same time to get feedback on potential improvements for faster progress. Public debate would support the development and improvement of co-ordination in the process of solving property rights crucial issues, contributing to further build public confidence in institutions and generate the needed wide inclusion of stakeholders for faster implementing reforms by guaranteeing longterm security of property rights. On the same path, this would enable and strengthen the communication among a wide range of geo data users and producers such as citizens, public authorities and private sector bridging over the present gap between them

\section{Online services as a medium of transparency and easy access...}

Still remains a challenge for the country, the development of an efficient and secure property administration system that will guarantee legal security to all stakeholders referring to legal properties historic. As a fundamental requisition to achieve this, can be considered the compatibility and consistency of data maintained and provided from different agencies especially

\footnotetext{
${ }^{1}$ Georgia and Czech Republic are successful cases of reforms on immovable property administration systems.
} 
land registry offices, cadaster offices and urban planning authorities. Once the digitalization of all data related to land registrars is properly accomplished, an online based services system could offer an easy access to digital property records for the public and facilitate procedures of property registration. Expanding access to information in the property registry would increase transparency, help owners to be clearly identified, and secure potential buyers for the legal status of the property, reducing thus transaction costs to determine who owns what and whittle down the time consumption for due diligence. Providing legal property information open for the public and investors potentially would diminish property rights pretending paving the way for faster and easier procedures in changing the ownership .For obtaining added benefit from the real estate sector, the role of registrars, notaries, solicitors and agents who participate in the transfer of land rights may positively change and the processes of land transfer may need to be modified to take advantage of information technologies. Forth view: Property tax as an instrument to induce efficient use of land For an economy, immovable property represents a fundamental asset which plays a determinant role in country's' market functioning. Due to this reason, secure immovable property legal titling is important for improving territorial planning and related strategic decision making. But, in parallel, property rights should be strictly followed by owners' responsibilities for an efficient use of property in compliance also with the territorial regulatory plan. There have been cases when an investor was unable to find available land to invest because of ownership conflicts or neglectful owners. In contradiction, the wasteland extension is still in considerable levels. To arrange an organized use of the Property rights issues in Albania: Challenges and perspective 25 land resources nationwide, authorities could consider a properties mapping not underestimating the effectiveness of property tax as an instrument to induce efficient utilization of the land. A property system of taxation should be put into service to clearly defined social objectives and provide a stable, predictable source of revenue that is transparent in the way that it is calculated and collected. These measures, mainly under the supervision of local authorities would encourage efficient use of land and property, discouraging land speculation which results in misused resources for Albanian economy. A welldesigned tax would recognize public claims on private property while allowing private property development and use optimization. Achieving these goals require strategic planning and analysis that is often a foreign concept but quite possible to traditionally state funded, output based organizations such as cadaster agencies. Under the scope of inducing efficient use of property use, improving the image and building confidence in property administration system through transparent public information on taxes is essential for an operational framework. Property owners need to be informed and understand the importance of property responsibilities.

\section{CONCLUSIONS}

The legal situation governing immovable property in Albania is very complex. The provisions of the applicable compensation laws and administrative procedures proved unsatisfactory so far. The rights of former owners remain unsettled to a significant extent. Albania acted with inefficacy regarding the creation of the necessary administrative infrastructure foreseen in the respective legal national acts. The Property Restitution and Compensation Law of 1993 provided for various forms of compensation when the original property could not be allocated to the former owners. The Council of Ministers which was supposed to define the detailed rules and methods for such compensation did not act efficiently. The bodies competent to deal with the compensation issues that emerged had not been set up and the situation had not changed with the entry into force of the Property Restitution and Compensation Law of 2004. Even after the adoption by the Parliament $(28 / 4 / 2005)$ of the Law determining the methodology for the valuation of the property for compensation, the situation did not change.

A stable legal framework, which creates legal security, is legitimate only if it is perceived as "just" by the population; in the case of property restitution, naturally, the population will be divided into the groups of the pre-1945 owners, the post-1991 owners and the illegal occupants. While the first two groups acquired the land legally and therefore are entitled to protection by the State, the latter may have claims based on falsified or false documents and/or threats to use force. The resolution of historical injustice must be the first step; therefore, any law and its implementation should be accepted by the majority of the pre-1945 owners, who ought to be consulted directly and involved seriously in the legislative drafting process.

However, remedying historical injustices should be kept out of the day-to-day politics and should not create new injustice; nobody who is entitled to protection by the State, because he or she has a valid legal title to property (as opposed to the illegal occupants), should be put in disadvantage or be disappointed in his or her trust in the law. Therefore, the post-1991 owners with proof of valid documents should be compensated and/or adequate new housing rights should be provided to them by the State. 


\section{References}

[1] Albania Progress Report", European Commission Staff Working Report, October 2012

[2] Doing Business 2013, World Bank Report 2013

[3] "Land policies for growth and poverty reduction: Key issues and challenges ahead", OECD Paper, Klaus Deininger (2005)

[4] "BEEPS At-A-Glance 2008" Albania report, The World Bank Group, January 2010

[5] "Governance in the Protection of Immovable Property Rights in Albania: A Continuing Challenge", World Bank Report No:62519-AL , June 2011

[6] "Land Administration in the UNECE Region. Development trends and main principles ", United Nations Economic Commission for Europe Guidelines (2005)

[7] Stanley and Adlington (2007)"World Bank Experience in Land Administration in the Transition Economies of Eastern Europe and Central Asia"

[8] "Crosscutting Strategy Reform in the Field of Property Rights 2012 - 2020", Ministry of Justice, Republic of Albania, June 2012

[9] Schargrodsky and Galiani (2006)"Property Rights for the Poor:Effects of Land Titling"

[10] Swinnen, Johan (1999)"An Explanation Of Land Reform Choices 